\title{
Chemical Glycobiology in Bacterial Surface Modification バクテリアのケミカルグライコバイオロジー
}

\author{
Morisaki, Chizu ${ }^{1}$; Uemura, Yusuke ${ }^{2}$; and Sadamoto, Reiko ${ }^{3}$ \\ ${ }^{1}$ Graduate School of Humanities and Sciences, Ochanomizu University, Bunkyo-ku, Tokyo 112-8610, Japan \\ ${ }^{2}$ Ochadai Academic Production, Ochanomizu University, Bunkyo-ku, Tokyo 112-8610 \\ ${ }^{3}$ Glycoscience Institute, Ochanomizu University, Bunkyo-ku, Tokyo 112-8610, Japan \\ FAX: 81-3-5978-5344 e-mail: sadamoto.reiko@ocha.ac.jp \\ (Received on October 22, 2012, accepted on December 7, 2012)
}

Key Words: chemical glycobiology, metabolic glycan labeling, bacteria cell surface engneering, genetic methods, imaging

\begin{abstract}
Recently, imaging of glycans on the cell surface has attracted much attention. There has been a good deal of research on glycan labeling for mammalian cells in vitro and also for some vertebrates (mice and zebrafish) in vivo, but little on bacterial cells. In this mini review, recent examples of chemical glycobiology, including various modification methods of bacterial surface carbohydrates which can be divided into genetic modification and nongenetic modification (metabolic labeling), are described.
\end{abstract}

\section{A. Introduction}

Recently, imaging of glycans on the cell surface has attracted much attention, particularly metabolic glycan labeling using cell biosynthesis pathways. The metabolic glycan labeling method is based on the metabolization of azide- or alkyne-containing nonnatural carbohydrates instead of natural carbohydrates, and the subsequent marking of the azides or alkynes on the cell surface with labeling compounds such as fluorophores. There has been a good deal of research on metabolic glycan labeling for mammalian cells in vitro and also for some vertebrates (mice and zebrafish) in vivo (1-3), but little on bacterial cells. In this minireview, we describe the current situation regarding bacterial cell surface glycan engineering, including our recent research.

\section{B. Surface Structure of Bacteria}

In this section, we explain the major structures of carbohydrates observed in the bacterial surface (Fig. 1)(4). Bacteria are divided into two types according to their surface structures: Grampositive and Gram-negative bacteria. Gram-positive bacteria, such as lactic acid bacteria, have thick peptidoglycan (cell wall) layers. The peptidoglycan consists of polysaccharides made up of GlcNAc$\beta(1 \rightarrow 4)$ MurNAc repeating units and short peptide chains crosslinking these polysaccharides. Gram-negative bacteria, on the other hand, have thin peptidoglycan layers and an outer membrane.

The outer membrane is an asymmetric bilayer consisting of
要 約

近年、細胞表面の糖鎖を可視化する研究が盛んに行われ ている。しかし、その多くの研究対象は主に動物細胞とマウ スやゼブラフィッシュなどの脊椎動物であり、バクテリアを 対象にしたものは比較的少ない。そこで、このミニレビュー では、バクテリアのケミカルグライコバイオロジーとして、 バクテリア表面糖鎖のさまざまな修飾法について、遺伝子組 換えを利用するものと遺伝子組換えを用いないメタボリック ラベリングに分けて紹介する。

\section{A. はじめに}

近年、細胞表面の糖鎖を可視化する研究が盛んに行われ ており、特に、細胞が持つ生合成経路を利用した糖鎖修飾 (metabolic glycan labeling) が注目を集めている。これは、糖 鎖の生合成経路に組み込まれうる糖誘導体に足場となる官能 基（例えば、アジド、アルキン）を持たせ、これを利用して 細胞表面を蛍光などで標識する方法である。動物細胞や脊椎 動物（魚類やマウスなど）をその研究対象にした例(1-3) は 数多いが、バクテリアの表層に存在する糖鎖を利用した研究 例はまだ少ない。そこで、このミニレビューではバクテリア の表面糖鎖修飾について、われわれがこれまで得てきた知見 とともに概説する。

\section{B. バクテリアの表面構造}

ここで、バクテリアの表面を構成する主な糖化合物につ いて簡単に触れておく (4) (Fig. 1)。バクテリアはその表面構 造から 2 種類に大別されることが知られている。一方は乳酸 菌やブドウ球菌に代表されるグラム陽性菌で、厚いペプチド グリカン層を持つ。ペプチドグリカンは、 $N$-アセチルグル コサミン (GlcNAc) と $N$-アセチルムラミン酸 (MurNAc) が $\beta$ $1 \rightarrow 4$ 結合した 2 糖単位の繰り返し構造の糖鎖と、その糖鎖同 士を架橋している短鎖ペプチドからなっている。もう一方は 大腸菌に代表されるグラム陰性菌で、ペプチドグリカン層が 薄く、その外側に外膜がある。 


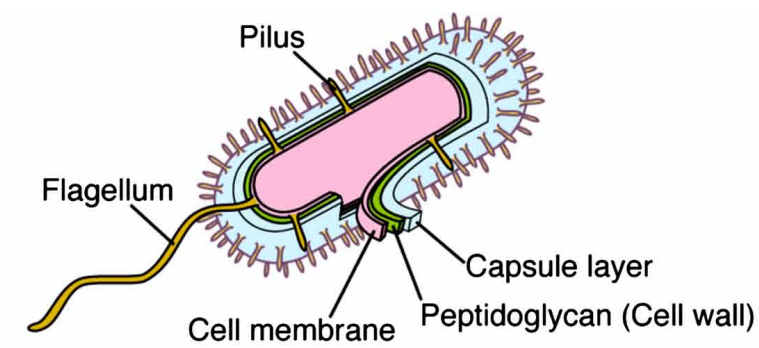

\section{Gram-positive bacteria}

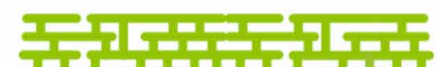

Peptidoglycan (Cell wall)

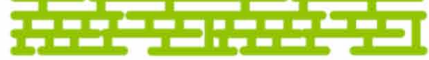

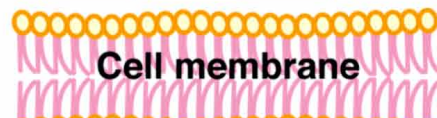
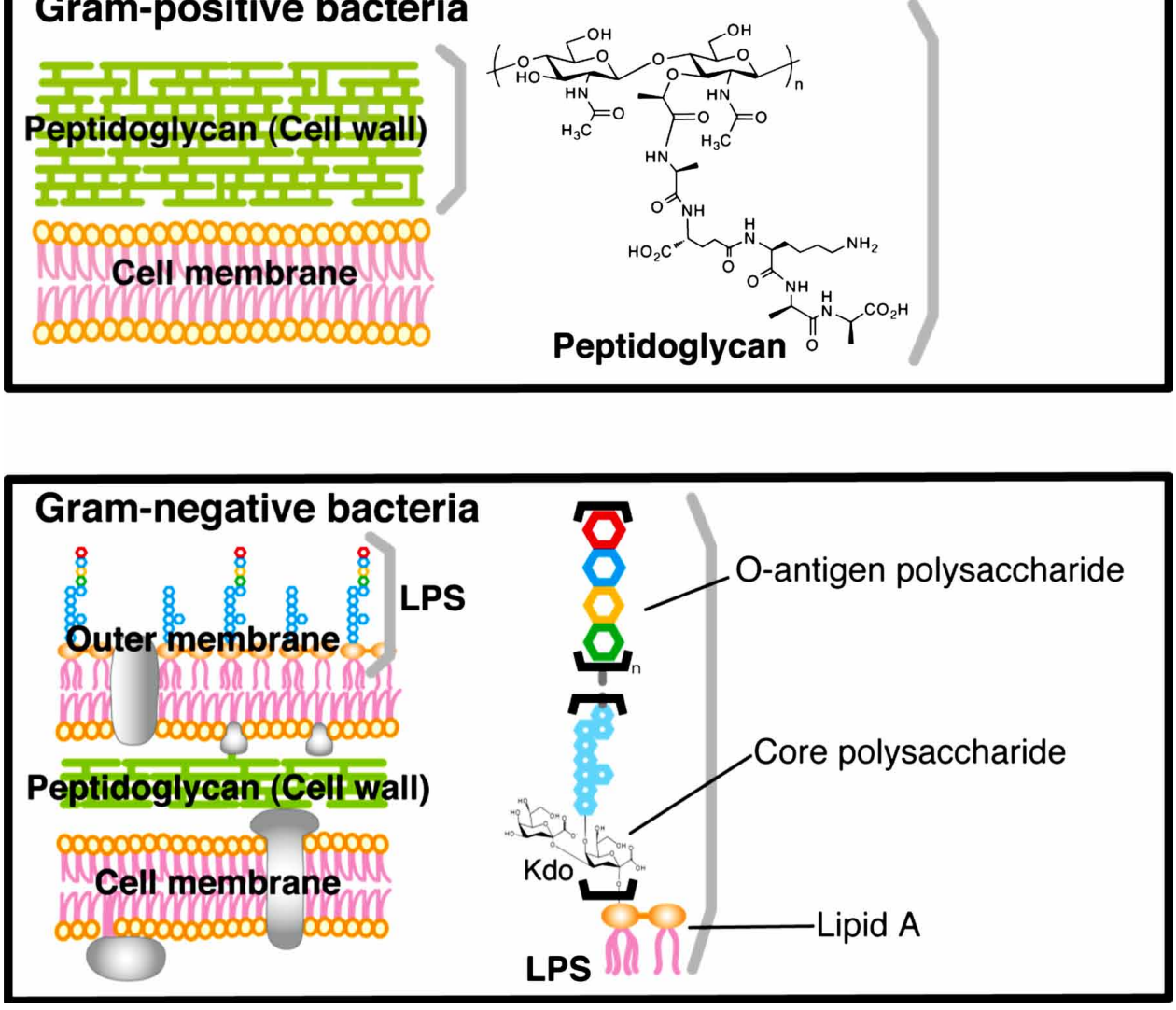

Fig. 1. The surface structure of bacteria. (Upper) Gram-positive bacterial surface. (Lower) Gram-negative bacterial surface

inner leaflet (phospholipid) and outer leaflet (lipopolysaccharide, LPS), which is a characteristic component of Gram-negative bacteria. LPS, also called endotoxin, have various biological activity including induction of fever and the dilation of blood vessels when it enters the blood stream of animals by bacteriolysis, occasionally resulting in a precipitous drop in the blood pressure. The main structures of LPS (from inside to outside) are lipid A, core polysaccharide, and $\mathrm{O}$-antigen polysaccharide. Lipid A has a carbohydrate unit, consisting of two glucosamine, to which some long fatty acid chains are attached. The core polysaccharide, connected to the glucosamine units, contains carbohydrates peculiar to Gram-negative bacteria, such as 3-deoxy-D-manno-oct-2-ulosonic acid (Kdo). The $\mathrm{O}$-antigen polysaccharide consists of oligo-saccharide repeating units that vary according to bacterial strains, and which is often
外膜は、外側のリン脂質と内側のリポ多糖 (Lipopolysaccharide, LPS）から構成される非対称の二重膜である。この LPS はグラム陰性菌に特徵的な成分で、エンドトキシン（細 胞内毒素）とも呼ばれ多くの生物活性を持ち、例えばヒトな ど動物の血液中に混入すると、発熱を誘導したり血管を拡 張させて急激な血圧低下をもたらすことがある。LPSの構造 は、内側から順にリピドA、コア多糖、O抗原多糖からなっ ている。リピドAはグルコサミン 2 個が結合した 2 糖に長い 脂肪酸側鎖が複数結合した糖脂質である。このグルコサミ ン部位に結合しているコア多糖には、3-deoxy-D-manno-oct2-ulosonic acid（Kdo）などグラム陰性菌に特徵的な糖が含ま れる。コア領域の外側に結合している $\mathrm{O}$ 抗原多糖は、菌株に よってその種類や配列が異なる繰り返し構造をもっており、 


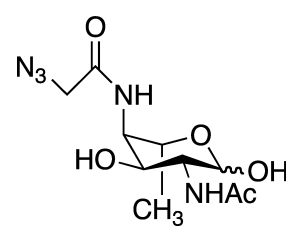

used to identify the bacterial strain.

Flagella, observed in various kinds of both Gram-positive and Gram-negative bacteria, are known to be related to motility. Many sites in the flagellin protein, the main component of flagella, are glycosylated. Flagellin antigens ( $\mathrm{H}$ antigens) are also used in the identification of Gram-negative bacteria strains: Eschericia coli $\mathrm{O} 157$ : H7 are pathogenic but E. coli $\mathrm{O} 157$ : H1 are generally nonpathogenic.

Other important carbohydrate compounds in the bacterial surface include teichoic acids and capsule polysaccharides.

\section{Bacterial Cell Surface Engineering Using Genetic Methods}

In this section, we provide a brief description of the modification of bacterial cell-surface carbohydrates using genetic engineering. Protein expression on the bacterial cell surface by genetic engineering is a popular technique, but there have been some recent reports on the display of reactive groups, such as an azide group, which can be used for further chemical labeling. Tirrell et al. succeeded in introducing non-natural amino acids, such as azidoalanine and azidohomoalanine, into outer membrane protein $\mathrm{C}$ (OmpC) of E. coli in place of methionine (Met) $(5,6)$. There are only three Met residues in E. coli $\mathrm{OmpC}$, and only one of them is exposed to the outside of the protein. Therefore, they added six Met residues, exposed to the outside, to OmpC by site-directed mutagenesis in order to increase the number of available functional sites. The $E$. coli was then cultured in a medium containing one of the methionine analogs (azidohomoalanine etc.) in place of Met. The cultured bacterial surface was labeled via copper(I)-catalyzed $[3+2]$ cycloaddition and analysed by flow cytometry.

Tanner et al. focused on pseudaminic acid (Pse) found on glycan of flagellin protein in Campylobacter jejuni, a common bacteria associated with food poisoning (7). Pse is a nine-carbon carbohydrate related to sialic acid and bacteria cannot make flagella, thereby losing their motility, when Pse is not available. As an azido-functional precursor of Pse, they prepared 2-acetamido4-azidoacetamido-2,4,6-trideoxy-L-altrose (6-deoxy-AltNAc4NAz, Fig. 2) via a chemoenzymatic approach, and added it to the culture medium for the genetically modified $C$. jejuni lacking the biosynthetic pathway for Pse. The cultured $C$. jejuni maintained motility due to the incorporation of the artificial Az-Pse into the flagella.
菌株の同定において一つの指標として用いられる。

鞭毛 (flagella) は、グラム陽性・陰性による表面構造の 違いとは直接関わりなく、さまざまな細菌に見られるもの で、運動性に関わっていることが多い。フラジェリンと呼ば れるタンパク質から構成されており、その多くのサイトがグ リコシル化されている。グラム陰性菌株同定には、O抗原に 加えて鞭毛抗原（H抗原）も用いられることがある。例えば、 食中毒の原因菌の一つである大腸菌に $0157:$ H7 があるが、 大腸菌 $\mathrm{O} 157$ : H1 株は毒性を持たない。

その他の糖化合物として、タイコ酸 (Teichoic acid) や夾 膜多糖 (capsule layer) が細胞表面に多く見られる。

\section{C. 遺伝子組換えを用いたバクテリア表面修飾法}

バクテリア表面修飾の方法として、遺伝子組換えを用い る手法を紹介する。遺伝子組換えを用いてバクテリア表面に 特定のタンパク質を発現させる手法はよく使われているが、 タンパク質を提示させるのではなく、アジド基などラベリン グに応用可能な反応性部位をバクテリアの表面に提示させる 手法もいくつか報告されている。

Tirrellらは、大腸菌の外膜に存在するタンパク質 outer membrane protein $\mathrm{C}(\mathrm{OmpC})$ にアジド基を持つ非天然アミノ 酸（アジドアラニン,アジドホモアラニンなど）をメチオ ニンの代わりに組み込むことに成功した $(5,6)$ 。大腸菌の $\mathrm{OmpC}$ には本来 3 力所のメチオニン部位があるが、そのうち 外側を向いているのは 1 力所だけである。そこで、外側に向 いた部位を新たに 6 力所遺伝子組換えにより導入した。その 大腸菌を、メチオニンを含まず代わりにアジドホモアラニン などのメチオニン誘導体を含む培地で増殖させた。培養した 大腸菌表面のアジド基を copper (I)-catalyzed [3+2] 環化付加 反応を用いてラベリングし、フローサイトメトリーなどで検 出・評価した。

Tannerらは食中毒の原因菌として知られるCampylobacter jejuniの鞭毛糖鎖にあるシュードアミン酸 (pseudaminic acid, Pse）に注目した（7）。Pseはシアル酸と関係の深 い9炭糖で、これがないと C. jejuniは鞭毛を形成することが できず、運動性を失う。Pseのアジド化した前駆体として、 2-acetamido-4-azidoacetamido-2,4,6-trideoxy-L-altrose (6-deoxyAltNAc4NAz, Fig. 2) を酵素反応と化学合成により合成し、 遺伝子組換えでPse 合成経路を欠いた . jejuni株の培地に添 加して培養した。培養したC. jejuniには運動性がみられ、ア ジド化されたPseによって鞭毛が形成されたことがわかっ た。また、導入されたアジド基がラベル化に使える状態で提 
(a)

(b)
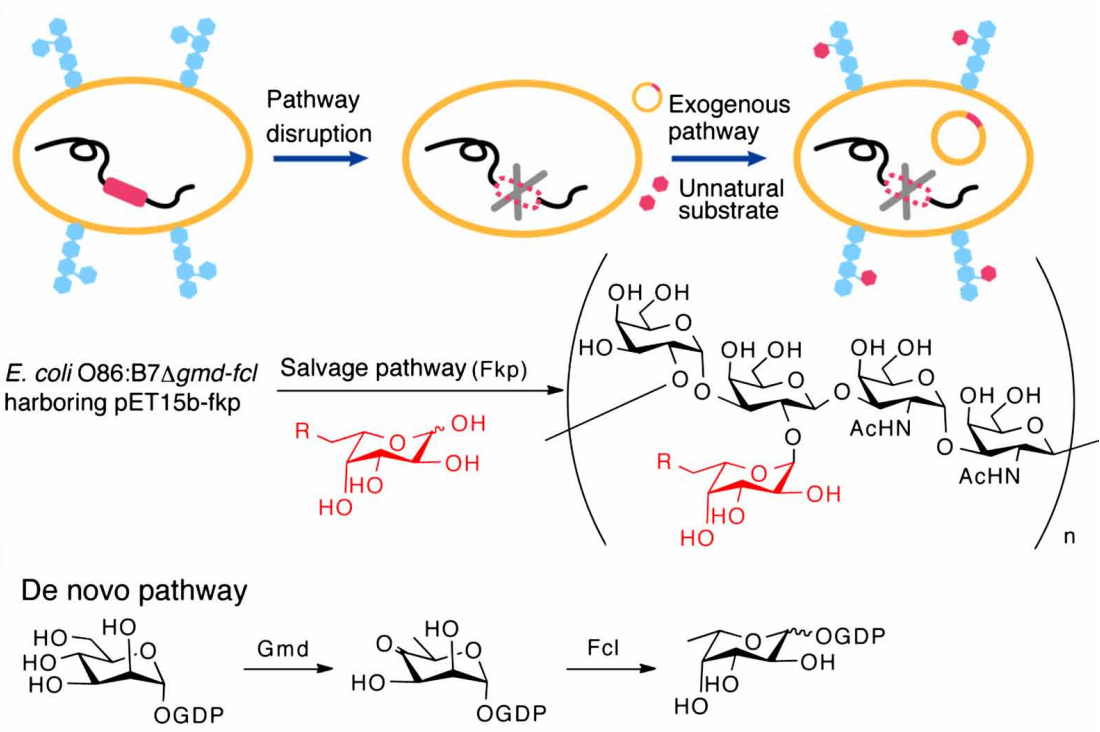

Salvage pathway

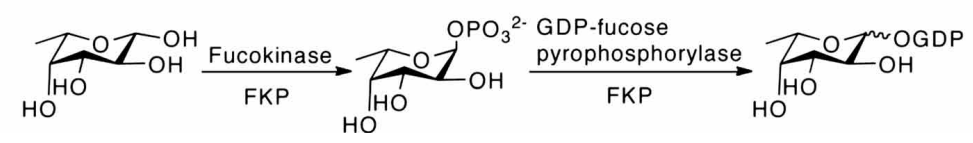

Fig. 3. Strategy for the generation of the modified O-antigen polysaccharide of $E$. coli O86. (a) A graphic representation of O-antigen polysaccharide modification using the genetic method. (b) Schema of the biosynthesis pathways for GDP-fucose: de novo pathway and salvage pathway.

They then confirmed the reactivity of the displayed azide group by labeling with biotin-conjugated Staudinger reagent.

Wang et al. used a fucose (Fuc) moiety in the O-antigen polysaccharide of E. coli O86 (8) (Fig. 3). There are two pathways for the biosynthesis for GDP-Fuc: the de novo pathway, which starts from GDP-mannose, and the salvage pathway, which starts from the phosphorylation of Fuc and the subsequent formation of GDPFuc. The de novo pathway is observed in both prokaryotes and eukaryotes, whereas the salvage pathway was thought to be present in eukaryotes only. However, Comstock et al. (9) found the salvage pathway in human symbionts Bacterioides. Therefore, Wang et al. used genetically modified E. coli $\mathrm{O} 86$ that did not have the original de novo pathway but possessed the salvage pathway in order to allow the incorporation of a C-6 azido fucose derivative (6- $\left.\mathrm{N}_{3}-\mathrm{Fuc}\right)$ into the repeating unit of $\mathrm{O}$ antigen.

\section{Bacterial Cell Surface Engineering Without Using Genetic Methods}

In this section, we introduce some methods of the bacterial surface modification that do not rely on genetic recombination techniques. These methods are based on the metabolization of artificial compounds via biosynthetic pathway for cell surface
示されていることを、biotin結合したStaudiger 試薬によるラ ベリングで確認した。

Wang らは大腸菌 O86 の O 抗原糖鎖にあるフコース (Fuc)を利用した (8) (Fig. 3a)。GDP-Fucの生合成経路には GDP-マンノースから出発する de novo pathwayと Fucがリン 酸化された後にGDP-Fucになる salvage pathwayの2つがしら れている (Fig. 3b)。de novo pathwayは原核生物、真核生物と もに持っているが、 salvage pathwayは真核生物しか持ってい ないと考えられてきた。しかし、2005年にComstockらによ り (9)、ヒトの常在菌である Bacteroidesが salvege pathwayを 持っていることが発見された。そこで彼らは、遺伝子組換え で大腸菌 O86の de novo pathwayをなくして salvage pathwayを 持たせた株に、C-6位をアジド化したフコース誘導体 (6- $\mathrm{N}_{3}$ Fuc）が生合成経路にのって O抗原リピート構造に組み込ま れるようにした。

\section{D. 遺伝子組換えを使用しないバクテリア表面修飾法 本項では、遺伝子組換え技術を使用することなく、バク テリア表面糖鎖を修飾した例について紹介する。この手法の 多くは、バクテリアの表面が作られるときの生合成経路を利 用して、人工的に用意した化合物を取り込ませることを基本 としている（メタボリックラベリング）。その化合物の設計}




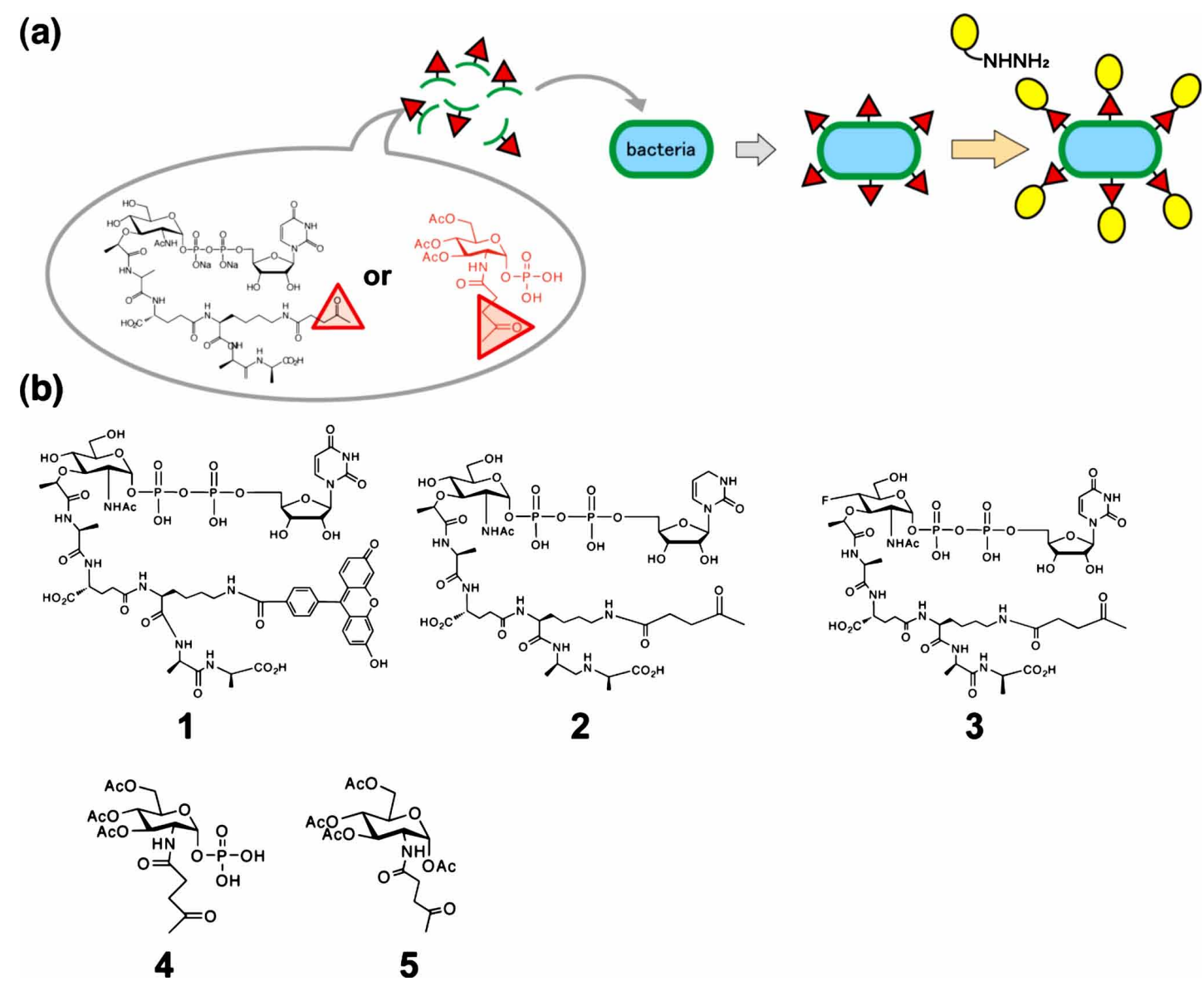

Fig. 4. Strategy for peptidoglycan modification. (a) A graphic representation of peptidoglycan modification using the chemical method. (b) Schema of GIcNAc derivatives.

materials (metabolic labeling). We can select a range of target bacteria depending on the compounds used as a precursor derivative in the metabolic labeling. This is one of the advantages compared to genetic approaches, in which we need to adapt each strain to be engineered. Therefore, metabolic labeling methods are expected to be a powerful tool for visualizing and identifying certain bacterial strains among many bacterial strains in a sample. Here we describe these modification methods targeting peptidoglycan and LPS.

\section{D-1. Metabolic Labeling Targeting Peptidoglycan}

Next, we explain the chemical modification of the bacterial cell surface targeting peptidoglycan. We reported our first peptidoglycan labeling methods in 2002 (10) (Fig. 4). As mentioned above in section B, most bacteria possess peptidoglycan, the structure of which is common except for a few residues in the oligopeptide, which cross-links the polysaccharide chains. Therefore, a surface engineering method targeting peptidoglycan can be applicable to almost all bacteria. The biosynthesis pathway of peptidoglycan is shown in Scheme 1. In the biosynthesis, UDP-GlcNAc is converted to UDP-MurNAc, and then an oligopeptide (often a penta-
によって対象となる細菌株の種類を選ぶことができるので、 それぞれの菌株ごとに作業しなけれげいけない遺伝子組換え 手法とは異なった特長を持っている。特に、多くの細菌のな かから特定の細菌を可視化して同定するなどイメージングへ の期待が大きい。ここでは、われわれが研究してきたぺプチ ドグリカンをターゲットにした手法と、最近報告されたLPS を標的とした修飾法について順に紹介する。

D-1. ペプチドグリカンをターゲットにしたメタボリック ラベリング

本項ではペプチドグリカンをターゲットにした化学的表 面修飾法について紹介する。ペプチドグリカンを修飾の標的 にする手法は、2002年に開発された (10) (Fig. 4)。B項で述 ベたように、ほとんどすべてのバクテリアはぺプチドグリカ ンをもっている。その構造は、糖鎖を架橋しているオリゴぺ プチド部分の構造はバクテリアによって部分的にやや違うこ ともあるが、主鎖の糖鎖構造は共通である。したがって、ぺ プチドグリカンをターゲットにする表面修飾法であれば、ほ とんどすべてのバクテリアへの応用が期待できる。ペプチド 

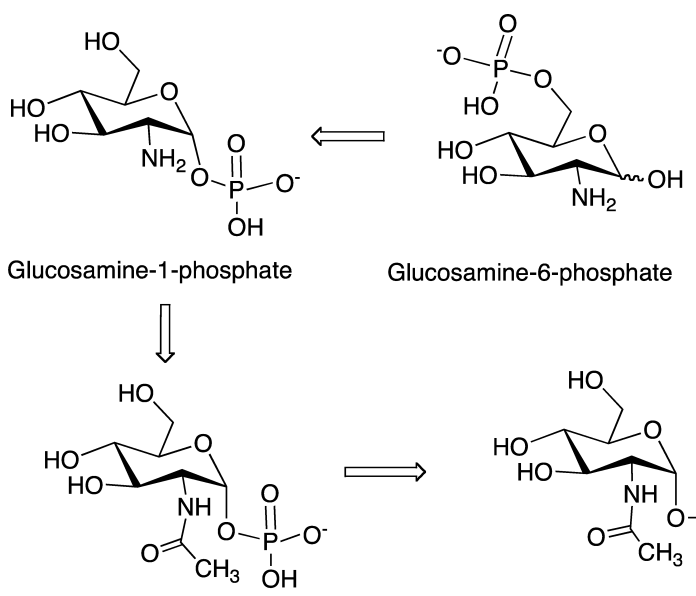

GlcNAc-1-phosphate

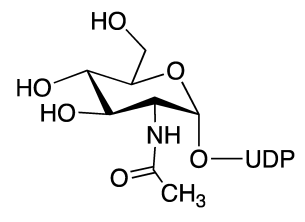

UDP-GICNAC

$\mathfrak{r}$

$\sqrt{ }$

$\sqrt{ }$
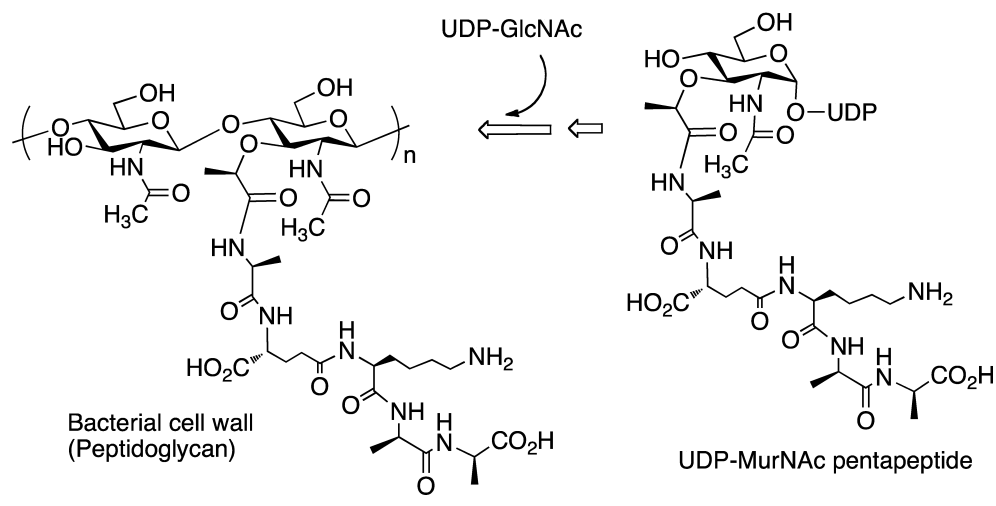

Scheme 1. Peptidoglycan biosynthesis

peptide) moiety is formed from the carboxyl group of the UDPMurNAc (Scheme 1).

First, we focused on UDP-MurNAc pentapeptide in the peptidoglycan biosynthesis pathway. The third residue in the pentapeptide moiety, lysine for example, has an additional amino group; therefore, we used the amino group for the introduction of a fluorophore (UDP-MurNAc pentapeptide derivative, 1). Next, four strains of bacteria (Lactobacillus plantarum JCM1149, L. salivarius JCM1044, L. fermentum no. 20, and E. coli C600) were cultured in a broth containing $\mathbf{1}$, and the peptidoglycan fractions from the culture were purified. All three strains of tested lactobacillus showed increased fluorescent intensity. In the case of the E. coli C600, fluorescence was observed only after additional treatment to increase the cell membrane permeability before incubation. E.coli, a typical Gram-negative bacterium with an outer membrane outside the peptidoglycan layer, may require permeabilization treatment in order to incorporate compound $\mathbf{1}$ within the cells. Observa-
グリカンの生合成経路 (Scheme 1) では、UDP-GlcNAcから、 UDP-MurNAcを経てこのムラミン酸のカルボン酸部位にア ミノ酸が（5残基のことが多い）が結合していき、UDP- $N-$ ア セチルムラミルペンタペプチド (UDP-MurNAc-pentapeptide) となることが知られている。

ペプチドグリカンの生合成経路に見られる中間体の中 で、われわれは初めにこのUDP-MurNAc-pentapeptide に着目 した。ペンタペプチド中の 3 番目の残基はリジンの場合が 多いので、このアミノ基にまず蛍光剤を導入した誘導体を 合成した $(\mathbf{1}) 。 4$ 種類のバクテリア（Lactobacillus plantarum JCM1149, L. salivarius JCM1044, and L. fermentum no. 20 と 大 腸菌 C600）をUDP-MurNAc-pentapeptide誘導体を含む培地で 培養し、溶菌後、ペプチドグリカン画分を精製しその蛍光強 度を測定したところ、3 種の乳酸菌では蛍光強度の増大が見 られた。大腸菌 C600株の場合は、培養前に外膜の透過性を 上げる処理をした場合だけ蛍光強度が増大した。大腸菌はグ ラム㓌性菌で、ペプチドグリカンの外側に外膜があるので、 
tion with a fluorescence microscopy showed fluorescence from the bacterial cells. After similar incubation using a ketone-functionalized dervative (2), instead of $\mathbf{1}$, the surface-displayed ketone moiety was detected via the coupling of a hydrazide-containing fluorophore. The observed fluorescence shows that the ketone moiety preserves its reactivity on the surface of the bacteria. According to this method, various molecules can be displayed on the surface of live bacteria using an appropriate linker that has a group reactive to the ketone moiety, such as hydrazide. For example, lactic acid bacteria displaying a ketone moiety were coated with a mannopentaose derivative containing an aminooxy group and showed stronger adhesion to a Con A (mannose-binding protein)-immobilized surface compared to the same strain without the displayed ketone group (11). Next, 4-fluorinated UDP-MurNAc pentapeptide derivative (3) was used as an inhibitor of peptidoglycan biosynthesis that works only when it was incorporated into the peptidoglycan. The fluorinated derivative $\mathbf{3}$ cannot proceed to the next step in the peptidoglycan synthesis, therefore, it should have a negative effect on bacterial growth. The growth of bacteria cultured in a media containing 3 was slower than the control without $\mathbf{3}$. This suggested that the UDP-MurNAc pentapeptide derivative could act as a peptidoglycan biosynthesis substrate (12-14).

As the UDP-MurNAc pentapeptide derivative needs multistep synthesis, the large-scale application of this method is difficult. To overcome these problems, we next focused on GlcNAc1-phosphate, which is a simple intermediate in the earlier steps of the peptidoglycan biosynthesis pathway. GlcNAc-1-phosphate can be an intermediate of both the MurNAc pentapeptide and GlcNAc component of peptidoglycan. In the peptidoglycan biosynthesis pathway, GlcNAc-1-phosphate is formed from glucosamine1-phosphate. Therefore, we chose GlcNAc-1-phosphate, and not GlcNAc, as the platform precursor for the introduction of ketone groups into the peptidoglycan. A GlcNAc-1-phosphate derivative (compound 4), in which a ketone group was introduced instead of the $N$-acetyl group of GlcNAc. Lactic acid bacteria (L. plantarum JCM1149) were incubated in a lactobacilli MRS broth containing 4. To detect the ketone moiety on the bacterial cell surface, collected bacteria were labeled with a biotin-PEO-hydrazide and streptavidin-Alexa Fluor conjugate, and analyzed using flow cytometry. The flow cytometric analysis showed an increase in fluorescence intensity, indicating that the bacteria displayed the ketone moiety on the cell surface (15). When GlcNAc derivative, $\mathbf{5}$, having no phosphate group, was used, no increase in fluorescence intensity was observed, suggesting that $\mathbf{4}$ was incorporated via the biosynthetic pathway.

For in vivo applications, it is important that the bacterial surface modification method does not affect mammalian cell cultur-
膜の透過性を高める処理が必要になったと思われる。また、 この蛍光ラベルしたバクテリアを蛍光顕微鏡で観察したとこ ろ、菌体からの蛍光が観察できた。次に、蛍光剤の代わりに ケトン基を導入した誘導体 (2)を用いて同様に培養後、提示 されたケトン基を検出するためにヒドラジド基をもつ蛍光剂 と反応させた。この場合も蛍光が検出され、ケトン基が利用 可能な状態でバクテリア表面に提示されていることが確かめ られた。本手法により、ケトン基と反応しやすいヒドラジド 基などを持つリンカーを利用してさまざまな分子を提示させ ることができるようになった。例えば、乳酸菌表面に、オキ シルアミノ基を導入したマンノペンタオース誘導体を結合さ せることで、菌体のコンカナバリン A を固定した基盤への接 着性を上げることができた (11)。次に、ペプチドグリカン生 合成経路に入ると生合成を阻害する誘導体として、4位のヒ ドロキシ基をフッ素に置換した誘導体 $(3)$ を合成した。4位 にフッ素を置換した誘導体が生合成経路にのった場合、ペプ チドグリカン合成が途中で止まり、乳酸菌の増殖に影響を与 えることが予想された。フッ素化パーヌクレオチドを乳酸菌 の培地に添加して培養すると、添加しないで培養した乳酸菌 に比べて増殖率が低下した。したがって、合成した誘導体 はペプチドグリカン生合成経路にのったことが推測された (12-14)。

この手法に用いるUDP-MurNAc-pentapeptide 誘導体は合 成ステップが複雑であるため、大量合成が難しかった。その ため、より簡単に合成できるぺプチドグリカン前駆体候補と して、ペプチドグリカンの生合成経路のより上流にある $N$ アセチルグルコサミン-1-リン酸に着目した。GlcNAc-1-リン 酸はムラミン酸部位とグルコサミン部位の両方に使われう るため、より効率的な前駆体となりうる。また、バクテリ アではGlcNAc-1-リン酸はグルコサミン-1-リン酸から生合成 されることが知られており、1位リン酸化後に2位アミノ基 がアセチル化される。したがって、ケトン基を導入する手 段として $N$-アセチルの部位を利用する場合、1位がリン酸化 された形で生合成経路にのせる必要がある。よって、グル コサミンの 2 位にレブリン酸を導入してケトン基を持たせた GlcNAc-1-リン酸誘導体 (4) 合成し、乳酸菌 (Lactobacillus plantarum JCM1149）の培地に添加して培養した。表面に提 示されたケトン基を検出するために、ビオチンヒドラジド、 ストレプトアビジン-Alexa複合体でラベルし、フローサイト メーターで菌体一つあたりの蛍光強度を検出したところ、ケ トン基の提示を観察することができた (15)。1位がリン酸化 されていないGlcNAc誘導体 $(\mathbf{5})$ を用いた場合は蛍光強度は 増加しなかったことから、この生合成経路を利用しているこ とが推測される。

次に、in vivoへの応用のためには、この誘導体を使った バクテリア表面修飾が、動物細胞に影響をあたえないことが 重要である。動物細胞（Jurkat細胞、Caco-2 細胞）の培養系 にこの誘導体を加えて、染色・フローサイトメーター測定を 行ったところ、蛍光強度の増大はみられなかった。また、使 用した濃度では細胞の増殖に影響は見られなかった。以上よ り、GlcNAc-1-リン酸誘導体はバクテリアのみに作用し、動 


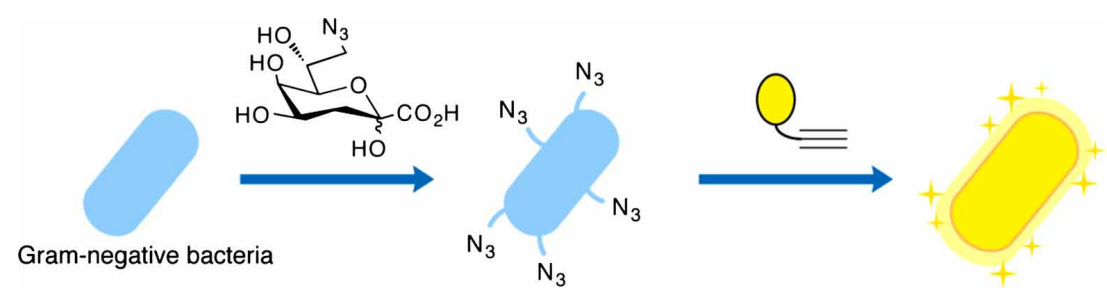

Fig. 5. Strategy for Kdo modification

ing. Mammalian cells (Jurkat and Caco-2) were incubated in a culture medium containing $\mathbf{4}$ and then analyzed using flow cytometry. Fluorescence was not observed for either cells. Both cells grew normally in the presence of $\mathbf{4}$ at the tested concentrations. These results indicate that $\mathbf{4}$ has an orthogonal property and is incorporated into bacteria but not mammalian cells (16). We are currently considering the in vivo application of this method.

Independent of the method described above, Spiegel et al. reported in 2010 that peptidoglycan can be labeled with compounds having a specific amino acid sequence (LPXTG), which are recognized by sortase (17).

\section{D-2. Metabolic Labeling Targeting LPS}

Gram-negative bacterial cell surface modification using Kdo derivatives has been reported (18) by Vauzeilles et al. (Fig. 5). The biosynthetic pathway of Kdo starts from the condensation of arabinose-5-phosphate with phosphoenolpyruvate. Kdo is then formed from the resulting Kdo-8-phosphate and becomes activated (CMP-Kdo) prior to incorporation into the core oligosaccharide of LPS. Vauzeilles et al. synthesized a Kdo derivative having an azide group at the $\mathrm{C} 8$ position, and used it for the surface modification of bacteria. Bacteria were incubated in a medium containing the Kdo derivative, and an alkyne fluorescence dye was used to label the azido moiety displayed on the surface of the bacteria for the detection with flow cytometry and microscopic observation. Among the tested bacteria, only Gram-negative bacteria, such as E. coli, showed strong fluorescence. This method can be used for the selective labeling of bacteria that have a Kdo moiety.

\section{E. Conclusion}

As part of our discussion of the chemical glycobiology of bacteria, we introduced various methods for the engineering of carbohydrates observed on the bacterial surface. The surface engineering methods are divided in two types: those with or without genetic modification. In the latter method, called metabolic labeling, bacteria can be selected according to the target structure on the bacterial surface, and various labeling compounds are available for the detection or even functionalization of the modified surface. Therefore, wide applications, including in vivo labeling techniques, are expected.
物細胞には影響を及ぼさないオルソゴナル性を示すことがわ かった (16)。現在、この手法のin vivoへの応用を検討してい る。

われわれのこの手法とは別に、ペプチドグリカンをター ゲットにした手法として、2010年に Spiegelらは、sortase酵 素を使用したラベリング手法を報告している(17)。この酵素 は、LPXTG配列を特異的に認識し、この中のスレオニン $(\mathrm{T})$ 残基とグリシン $(\mathrm{G})$ 残基の結合を切断し、スレオニン $(\mathrm{T})$ 残 基と Lipid II のペンタグリシン架橋部の $\mathrm{N}$ 末端部分を結合さ せる働きをする。彼らは、この酵素によって認識される特異 的配列（LPXTG）を持たせた分子をぺプチドグリカンに結合 させるラベリング手法を実現した。

D-2. LPSをターゲットにしたメタボリックラベリング

グラム㓌性菌全体を化学修飾できるような例として、 2012 年にVauzeillesらにより報告された (18)、Kdo 誘導体 を用いて大腸菌の LPS を修飾する手法を解説する（Fig. 5）。 Kdoは次のようにLPSに取り达まれる。まず、アラビノース -5-リン酸がホスホエノールピルビン酸と縮合しKdo-8-リン 酸となり、その後、遊離の Kdo を経て CMP-Kdo として活性 化されてLPSに組み込まれる。彼らは、Kdoの8位をアジド で修飾した化合物（以下、Kdo誘導体）を合成し表面修飾に 用いた。この Kdo 誘導体を加えた培地でさまざまな細菌を培 養し、それぞれの表面のアジド基をアルキンを持った蛍光剂 を用いて蛍光ラベルして、フローサイトメトリーや蛍光顕微 鏡観察により解析した。その結果、大腸菌などのグラム陰性 菌だけに強い蛍光が観測されることがわかった。この方法に より、Kdoを持つバクテリアだけをラベリングすることがで きる。

E. おわりに

このミニレビューでは、バクテリアを対象にしたケミカ ルグライコバイオロジーとして、さまざまな表面糖鎖修飾法 を紹介した。バクテリア表面修飾法には、遺伝子組換えを利 用した方法と利用しない方法がある。後者は特にメタボリッ クラベリングとも呼ばれ、バクテリア表層構造のどの部位を 標識化のターゲットにして標識化される細菌群を選ぶか、ど のような化合物で修飾し効率的なラベル化や機能化を目指す かなど、in vivoへの応用も含めてこれからの研究の発展が期 待される。 


\section{References}

1. Prescher, J. A., Dube, D. H., and Bertozzi, C. R. (2004) Nature. 430, 873-877.

2. Laughlin, S. T., Baskin, J. M., Amacher, S. L., and Bertozzi, C. R. (2008) Science. 320, 664-667.

3. Baskin, J. M., Dehnert, K. W., Laughlin, S. T., Amacher, S. L., and Bertozzi, C. R. (2010) Proc. Natl. Acad. Sci. U.S.A. 107, $10360-10365$.

4. Black, J. G., and Lewis, L. M. (2005) Microbiology: principles and explorations, 6th ed., John Wiley, Hoboken, N.J.

5. Link, A. J., and Tirrell, D. A. (2003) J. Am. Chem. Soc. 125, 11164-11165.

6. Link, A. J., Vink, M. K., and Tirrell, D. A. (2004) J. Am. Chem. Soc. 126, 10598-10602.

7. Liu, F., Aubry, A. J., Schoenhofen, I. C., Logan, S. M., and Tanner, M. E. (2009) ChemBioChem. 10, 1317-1320.

8. Yi, W., Liu, X., Li, Y., Li, J., Xia, C., Zhou, G., Zhang, W., Zhao, W., Chen, X., and Wang, P. G. (2009) Proc. Natl. Acad. Sci. U.S.A. 106, 42074212.

9. Coyne, M. J., Reinap, B., Lee, M. M., and Comstock, L. E. (2005) Science. 307, 1778-1781.

10. Sadamoto, R., Niikura, K., Sears, P. S., Liu, H., Wong, C.-H., Suksomcheep, A., Tomita, F., Monde, K., and Nishimura, S.-I. (2002) J. Am. Chem. Soc. 124, 9018-9019.

11. Sadamoto, R., Niikura, K., Ueda, T., Monde, K., Fukuhara, N., and Nishimura, S.-I. (2004) J. Am. Chem. Soc. 126, $3755-3761$.

12. Sadamoto, R., Niikura, K., Monde, K., and Nishimura, S.-I. (2003) Methods Enzymol. 362, 273-286.

13. Ueda, T., Feng, F., Sadamoto, R., Niikura, K., Monde, K., and Nishimura, S.-I. (2004) Org. Lett. 6, 1753-1756.

14. Sadamoto, R. (2005) Trends Glycosci. Glycotechnol. 17, 97-105.

15. Sadamoto, R., Matsubayashi, T., Shimizu, M., Ueda, T., Koshida, S., Koda, T., and Nishimura, S.-I. (2008) Chemistry. 14, $10192-10195$.

16. Morisaki, C., Sato, Y., Oohori, M., Tsuri, R., Sekimata, K., and Sadamoto, R. (2010) Pacifichem 2010, International Chemical Congress of Pacific Basin Societies, Honolulu, HI, United States, HEALTH-291.

17. Nelson, J. W., Chamessian, A. G., McEnaney, P. J., Murelli, R. P., Kazmierczak, B. I., and Spiegel, D. A. (2010) ACS Chem. Biol. 5, 1147-1155.

18. Dumont, A., Malleron, A., Awwad, M., Dukan, S., and Vauzeilles, B. (2012) Angew. Chem. Int. Ed. 51, 3143-3146.

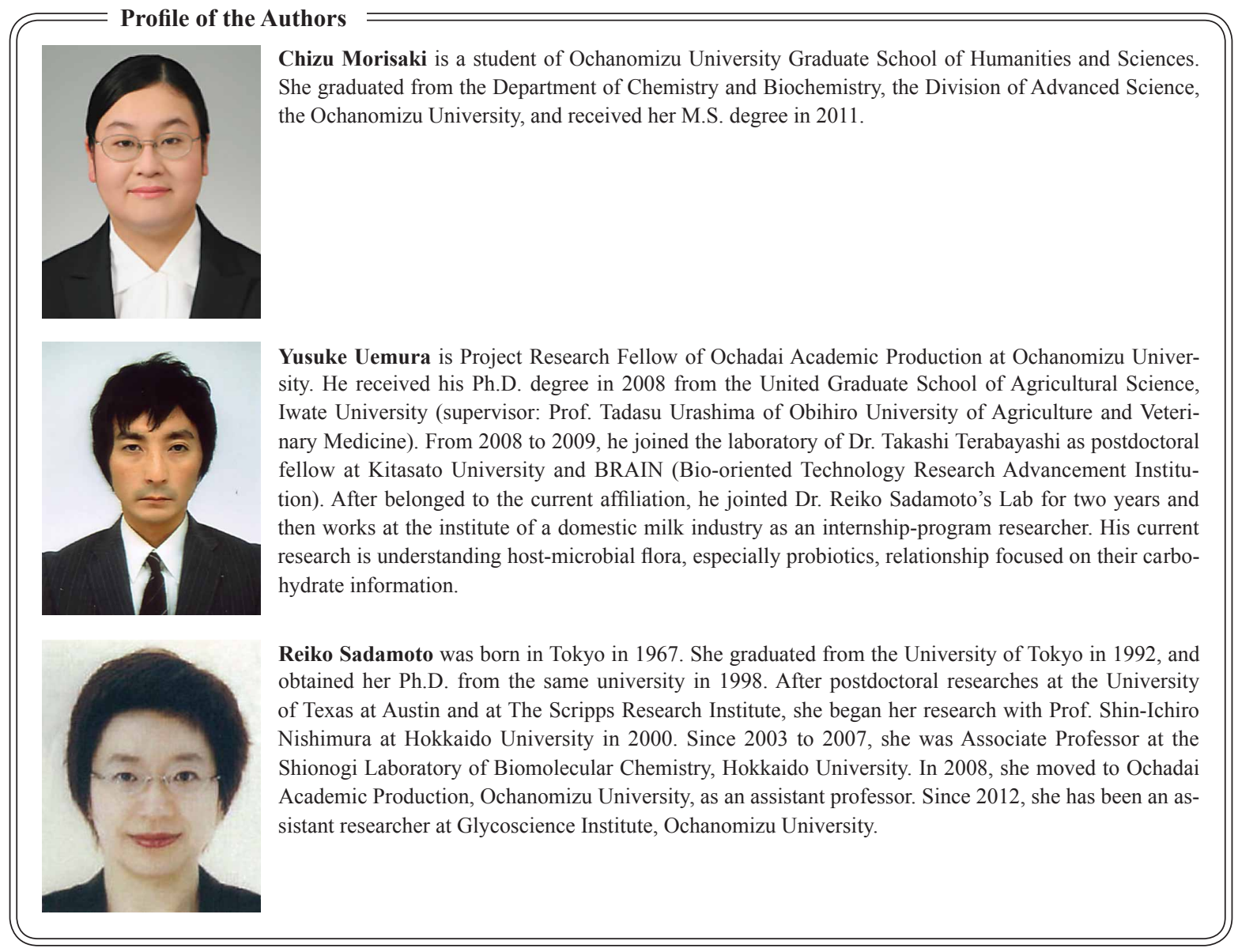

